\title{
Improved detection of acute parvovirus B19 infection by immunoglobulin $M$ EIA in combination with a novel antigen EIA
}

\author{
A. Corcoran, ${ }^{1}$ S. Kerr, ${ }^{1}$ G. Elliott, ${ }^{1}$ M. Koppelman ${ }^{2}$ \& S. Doyle ${ }^{3}$ \\ ${ }^{1}$ Biotrin International, Dublin, Ireland \\ ${ }^{2}$ Sanquin Diagnostic Services, Plesmanlaan 125, Amsterdam, The Netherlands \\ ${ }^{3}$ National Institute for Cellular Biotechnology, National University of Ireland Maynooth, Co. Kildare, Ireland
}

Background and Objectives Although parvovirus B19 is a significant blood product contaminant, few methods other than polymerase chain reaction (PCR) have been developed to detect the presence of the virus.

Material and Methods A B19 antigen enzyme immunoassay (EIA) has been developed and the sensitivity of detection is ascertained using dilutions of the B19 capsid protein VP2 and 10-fold dilutions of B19 viraemic serum. Once the assay cut-off was established, a panel of viraemic donations $(n=70)$ was screened by the antigen EIA. The B19 immunoglobulin M (IgM) and IgG status of these specimens was also determined. During screening of blood donor units by quantitative PCR, 70 individuals were identified with levels of B19 DNA greater than $10^{6} \mathrm{IU} / \mathrm{ml}$ at the time of blood donation.

Results The sensitivity of the B19 antigen EIA was estimated to be equivalent to between $10^{8}$ and $10^{9} \mathrm{IU} / \mathrm{ml} \mathrm{B19}$ DNA or $1-10 \mathrm{pg} / \mathrm{ml}$ of recombinant capsid protein. B19 detection was significantly enhanced when viraemic specimens were pretreated with a low $\mathrm{pH}$ proprietary reagent. Unlike other virus-detection assays, detection of the B19 antigen was not affected by the presence of B19 IgM or IgG antibodies. In addition, the assay was capable of detecting all three genotypes of human erythrovirus. Combined specimen analysis by the B19 antigen assay and a B19 IgM assay facilitated the detection of 91\% of acute B19 infections in the test population.

Received: 19 February 2007,

revised 14 June 2007 ,

accepted 16 June 2007 ,

published online 7 August 2007
Conclusion In combination with B19 IgM detection, application of the B19 antigen EIA is a flexible and efficient method of detecting recent B19 infection and can be used as an alternative to PCR.

Key words: antigen EIA, B19 IgM, blood products, erythrovirus.

\section{Introduction}

Parvovirus B19 (B19V) infection of immunocompromised patients may result in severe morbidity and mortality $[1,2]$. Moreover, B19 infection of pregnant women may lead to

Correspondence: Amanda Corcoran, Biotrin International, 93 The Rise, Mount Merrion, Co. Dublin, Ireland

E-mail: amanda.corcoran@biotrin.ie fetal death [3]. The recent implementation of minipool polymerase chain reaction (PCR) screening procedures for pooled plasma, combined with mandatory European guidelines on acceptable B19 contamination of human immunoglobulin preparations (< $10000 \mathrm{IU} / \mathrm{ml}$ B19 DNA), will minimize B19 contamination and improve the safety of pooled blood products $[4,5]$. However, the extremely high levels of B19 viraemia in recently infected individuals ( $10^{13} \mathrm{IU}$ B 19 DNA/ml) [6], asymptomatic B19 infections and the resilience of the virus to many of the virus-inactivation procedures mean that 
B19 screening and elimination are still problematic $[7,8]$. Although PCR is currently the method of choice, contamination issues during screening [9], accurate erythrovirus genotype detection [10] and lack of individual donation screening necessitate continual evaluation of emerging technologies to ensure blood product safety.

Currently, B19 viral capsid protein production in vivo is detected by immunofluorescent staining and receptormediated haemagglutination (RHA) assays whereas viral DNA production is detected by PCR, dot blot hybridization and quantitative PCR (qPCR) [11-15]. RHA does not detect the $\mathrm{B} 19$ antigen at the required sensitivity in specimens that contain B19 $\mathrm{IgG} / \mathrm{M}[11,15]$. This is unacceptable especially when B19 IgG positive solvent/detergent-treated plasma, contaminated with B19 DNA, has been shown to transmit infection [16].

B19 antigen detection by enzyme immunoassay (EIA) is an alternative strategy for individual donor screening but may also be confounded by low assay sensitivity, differential reactivity between VP2 capsid and native B19 antigen detection and B19 antibody presence [17,18]. The B19 antigen assay described by Lowin et al. [18] has an apparent sensitivity of detection for recombinant VP2 capsids of $10^{8}$ particles per $\mathrm{ml}$; however, application of the assay to native B19 antigen detection was not demonstrated.

Using a Food and Drug Administration (FDA)-cleared B19 IgM EIA [19], Beersma et al. [20] have shown that in sera with B19 DNA levels greater than $10^{6}$ per ml, B19 IgM reactivity always exceeds $3 \cdot 0$ (EIA cut-off $=1 \cdot 0$ ). Thus, it is clear that the presence of B19 VP2 IgM antibodies in sera is predictive for the presence of B19 DNA. This observation represents the first data unambiguously correlating B19 viral load with IgM antibody levels. Importantly, it also provides for an alternative strategy, employing simultaneous B19 IgM and antigen detection, to overcome the sensitivity issues pertaining to B19 antigen detection in individual donor units. Here, we show that such a strategy facilitates detection of B19 antigen levels in plasma donations.

\section{Materials and methods}

\section{B19 antigen EIA optimization}

Recombinant B19 VP2 capsids were expressed and purified as previously described [21] and were used for sheep and rabbit immunization. Affinity purified sheep IgG (anti-B19 VP2) was coated onto microtitre plates (Nunc Maxisorp, Roskilde, Denmark) and the rabbit IgG (anti-B19 VP2) was conjugated to horseradish peroxidase (HRP), as described by Hermanson [22], and was used to detect captured B19 antigen.

Optimal IgG (anti-B19 VP2) plate-coating concentration ( $4 \mu \mathrm{g} / \mathrm{ml})$ and conjugate dilution (1/4000 dilution) were established by testing B19-viraemic and non-viraemic plasma specimens. Dilutions of B19 VP2 capsids from $0 \cdot 01$ to $10000 \mathrm{ng} / \mathrm{ml}$ were also analysed by the antigen EIA to determine the limit of detection in terms of protein concentration. The mean absorbance of the negative control for each batch of VP2 plus three standard deviations was used to set the assay cut-off value (COV).

To determine sensitivity in terms of B19 viral antigen detection, viraemic plasma was evaluated (qPCR testing was performed at the National Genetics Institute, CA, USA and results were reported in copies $/ \mathrm{ml}$ ). The mean absorbance of a panel of 201 non-viraemic human plasma samples plus three standard deviations was used to set the assay COV. This was matched to a dilution of a B19-viraemic plasma, which was used in all subsequent assays as a cut-off calibrator and facilitated determination of the positive or negative status of specimens tested on the antigen EIA.

\section{Specimen preparation and final assay procedure}

Test plasma and control specimens were diluted (1/5) in a low $\mathrm{pH}$ proprietary diluent (citrate buffer-containing detergents; available from Biotrin International Ltd., Dublin, Ireland) and were added to IgG (anti-B19 VP2) sensitized microwells (100 $\mu \mathrm{l}$ per well) for $1 \mathrm{~h}$. Following a wash step, the rabbit IgG (anti-B19 VP2)-HRP conjugate was incubated in the wells for $30 \mathrm{~min}$. Tetramethylbenzidine substrate (BioFX Laboratories Inc., Owings Mills, MD, USA) was added to the wells for $30 \mathrm{~min}$. The reaction was terminated using $1 \mathrm{~N}$ sulphuric acid and the absorbance was measured at 450/630 $\mathrm{nm}$. The presence of B19 antigen in a sample was determined by the absorbance ratio of specimen sample to cut-off calibrator sample (index value; IV). Specimens yielding index values $\geq 1.0$ were classed positive while those $<1.0$ were deemed negative.

\section{Parvovirus B19 IgM and IgG}

All specimens in this study were screened for B19 IgM and B19 IgG using commercial assays (Biotrin) as described previously [21].

\section{Donor screening by B19 qPCR}

The blood donor population in The Netherlands was screened for B19V over an 18-month period (February 2003 -July 2004) using qPCR analysis as described previously [12]. Test pools of 480 were made from smaller pools of 48 donations. A pool identified with $>10^{4} \mathrm{IU} / \mathrm{ml}$ B19 DNA was resolved via test pools of 48 donations and subsequently eight donations to trace the viraemic donor(s). Identified viraemic donations $(n=70)$ were then used to evaluate the B19 antigen EIA [12]. Results were expressed in IU/ml [23]. The copies-to-IU conversion factor has been calculated previously to be $3 \cdot 34$ [14]. 

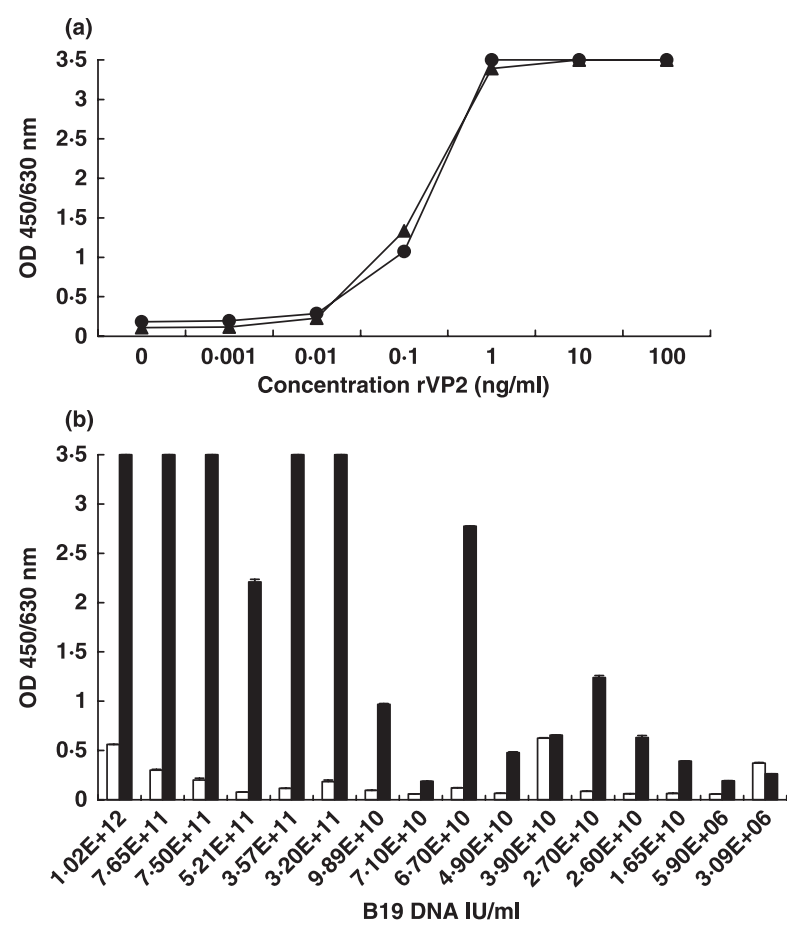

Fig. 1 Determination of B19 antigen enzyme immunoassay (EIA) assay sensitivity. (a) Two independent batches of recombinant capsid VP2 (rVP2), V056 (circles) and V057 (triangles) were decimally diluted to determine assay sensitivity. (b) Comparison of specimen diluents used in the detection of B19 viral capsids. Specimens were diluted in either Tris-buffered saline Tween-20 (TBST) (clear boxes) or a low pH proprietary reagent (filled boxes). Error bars represent the standard deviation from the mean.

\section{Results}

\section{Assay optimization and validation}

Figure 1a shows identical standard curves [absorbance ${ }_{450 / 630 ~ n m}$ vs. B19 recombinant VP2 capsid concentration (ng/ml)] generated from two independent batches of recombinant VP2 capsids in the B19 antigen EIA. These standard curves show that the minimal detectable level of B19 VP2 capsid detectable was $0.01 \mathrm{ng} / \mathrm{ml}$, which theoretically equates to $1.9 \times 10^{6}$ viral particles per ml.

However, detection of B19 viraemic plasma in the same assay format required the implementation of an alternative specimen diluent (Fig. 1b). Here, dilution of viraemic specimens ( $n=16)$ in a low $\mathrm{pH}$, proprietary diluent, compared to using Tris-buffered saline Tween-20 (TBST), facilitated a considerable increase in virus capture in the majority of specimens (0- to 30 -fold). Only one specimen $\left(3.9 \times 10^{10} \mathrm{IU} / \mathrm{ml}\right.$ B19 DNA) that was negative for B19 IgM did not display a significant signal increase post-treatment, but did remain positive. Interestingly, the two specimens with the highest absorbance values in the assay without low $\mathrm{pH}$ pretreatment were IgM negative.

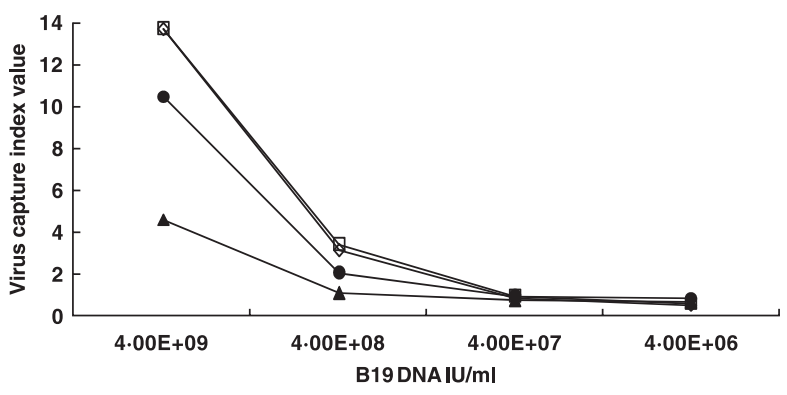

Fig. 2 Determination of antigen assay sensitivity using titrations of polymerase chain reaction (PCR)-quantified viraemic specimens. Viraemic plasma Bt72 (diamonds), Bt73 (squares), Bt80 (triangles) and genotype 2 Bt81 (circles) were decimally diluted in B19 negative serum to determine assay cut-off.

Non-viraemic plasma remained unreactive when subjected to the same pretreatment (data not shown). Assay specificity was determined by screening non-viraemic plasma $(n=20)$, all of which were unreactive in the antigen EIA based on the cut-off calibrator sample (data not shown).

The assay sensitivity (limit of detection) was estimated using dilutions of viraemic specimens and was shown to be approximately between $4 \times 10^{7}$ and $4 \times 10^{8}$ copies per ml B19 DNA (Fig. 2). However, the cut-off calibrator used in the EIA contained $10^{9}$ copies per ml B19 DNA as determined by qPCR, which equates to $2 \times 10^{7}$ copies B19 DNA per microwell. To further define the limit of detection, plasma specimens ( $n=17$ ), containing a range of B19 DNA concentrations and B19 IgM/G reactivity, were subsequently screened in the antigen EIA. Table 1 shows that 53\% (9/17) of specimens, all of which contained greater than $1.4 \times 10^{11}$ copies per ml B19 DNA, were also detectable in the antigen EIA. One specimen containing $7 \cdot 2 \times 10^{8}$ copies per ml B19 DNA, which was B19 IgM reactive, tested borderline positive (IV $=1 \cdot 0)$ in the antigen EIA. All remaining specimens, which contained less than $1.9 \times 10^{7}$ copies per ml B19 DNA and either B19 IgM or IgG or both, were unreactive in the antigen EIA.

Detection of the B19 antigen in the presence of specimenderived B19-specific IgG or IgM is essential to avoid false negativity. Table 2 clearly illustrates that specimen-derived B19 antigen is detectable in the presence of both B19 IgG and IgM ( $n=8)$, IgM only $(n=2)$ or IgG only $(n=3)$. Furthermore, B19 antigen is also detectable in specimens Bt72 and Bt73, which contained B19 IgM (Fig. 2). It is clear, therefore, that only B19 levels greater than $4 \times 10^{7}$ B19 DNA copies per ml are detectable in the antigen EIA and that the presence or absence of IgM or IgG in the specimen does not affect detection of the B19 antigen (Fig. 2 and Table 2). A specimen containing erythrovirus genotype 2 (specimen Bt81) was detected as well as erythrovirus genotype 1 (specimens Bt72, Bt73 and Bt80) in the antigen EIA (Fig. 2). Furthermore, erythrovirus genotype 
Table 1 Parvovirus B19 detection by antigen enzyme immunoassay (EIA) and serological analysis (B19 IgM and $\lg \mathrm{G}$ ) of specimens previously quantified by polymerase chain reaction (PCR) (copies per $\mathrm{ml}$ ). For the antigen EIA an index value (IV) $\geq 1.0$ is positive ( + ) and $<1.0$ is deemed negative (-). For both the B19 IgM and $\operatorname{IgG}$ EIA IV $>1 \cdot 1$ is positive; IV $<0.9$ is negative; and IV between $<1.1$ and IV $>0.9$ is deemed equivocal (eq)

\begin{tabular}{|c|c|c|c|c|c|c|c|}
\hline Sample identifier & IgM EIA & IV & IgG EIA & IV & qPCR (copies per ml) & Antigen EIA & IV \\
\hline Cut-off calibrator & $6 \cdot 77$ & + & 0.99 & eq & $1.3 \times 10^{9}$ & 1.00 & + \\
\hline WP & $0 \cdot 80$ & - & $0 \cdot 14$ & - & $6.9 \times 10^{11}$ & $18 \cdot 7$ & + \\
\hline $\mathrm{C} 4$ & $0 \cdot 26$ & - & 0.06 & - & $6.0 \times 10^{11}$ & $>3 \cdot 0$ & + \\
\hline PL19 & 0.59 & - & 0.07 & - & $5.6 \times 10^{11}$ & $>3.0$ & + \\
\hline $\mathrm{C} 7$ & 0.58 & - & 0.06 & - & $5.5 \times 10^{11}$ & $>3 \cdot 0$ & + \\
\hline $\mathrm{C} 1$ & $0 \cdot 13$ & - & 0.04 & - & $4.8 \times 10^{11}$ & $>3 \cdot 0$ & + \\
\hline $\mathrm{C} 2$ & 0.08 & - & 0.06 & - & $4.6 \times 10^{11}$ & $>3.0$ & + \\
\hline $\mathrm{C} 6$ & $0 \cdot 24$ & - & 0.05 & - & $3.3 \times 10^{11}$ & $>3 \cdot 0$ & + \\
\hline $\mathrm{C} 3$ & 0.08 & - & 0.09 & - & $3.9 \times 10^{11}$ & $>3 \cdot 0$ & + \\
\hline PL9 & $0 \cdot 11$ & - & 0.06 & - & $1.4 \times 10^{11}$ & $>11 \cdot 0$ & + \\
\hline $\mathrm{C} 5$ & $2 \cdot 02$ & + & $0 \cdot 17$ & - & $7 \cdot 2 \times 10^{8}$ & $1 \cdot 0$ & + \\
\hline ER & $3 \cdot 0$ & + & $8 \cdot 1$ & + & $1.9 \times 10^{7}$ & 0.03 & - \\
\hline PL1 & $6 \cdot 3$ & + & 1.95 & + & $1.6 \times 10^{7}$ & $0 \cdot 39$ & - \\
\hline $\mathrm{C} 8$ & $0 \cdot 15$ & - & $2 \cdot 56$ & + & $2.6 \times 10^{4}$ & 0.04 & - \\
\hline D T & $2 \cdot 3$ & + & $6 \cdot 2$ & + & $7 \cdot 4 \times 10^{3}$ & 0.07 & - \\
\hline RS & $6 \cdot 6$ & + & 6.8 & + & $8.9 \times 10^{3}$ & 0.42 & - \\
\hline PL20 & $0 \cdot 11$ & - & $4 \cdot 78$ & + & 550 & $0 \cdot 42$ & - \\
\hline PL16 & $0 \cdot 2$ & - & $4 \cdot 80$ & + & 200 & 0.39 & - \\
\hline
\end{tabular}

Table 2 Effect of B19 IgM and IgG in plasma on the detection of B19 antigen. B19 antigen enzyme immunoassay (EIA) and serology results for plasma from patients with suspected B19 infection. For the antigen EIA an index value (IV) $\geq 1.0$ is positive ( + ) and $<1.0$ is deemed negative (-). For both the B19 IgM and IgG EIA an IV > 1.1 is positive; IV < 0.9 is negative; and IV between $<1.1$ and $>0.9$ is deemed equivocal $(e q)$

\begin{tabular}{|c|c|c|c|c|c|}
\hline Sample Identifier & IgM EIA & IV & IgG EIA & IV & Antigen EIA IV \\
\hline Cut-off calibrator & $6 \cdot 77$ & + & 0.99 & $e q$ & 1 \\
\hline 931 & $0 \cdot 14$ & - & $0 \cdot 70$ & - & $18 \cdot 6$ \\
\hline 420 & $0 \cdot 16$ & - & 0.90 & $e q$ & $18 \cdot 3$ \\
\hline 981 & $1 \cdot 73$ & + & 1.50 & + & $18 \cdot 1$ \\
\hline 410 & $0 \cdot 25$ & - & $0 \cdot 90$ & eq & $18 \cdot 1$ \\
\hline 375 & $0 \cdot 14$ & - & $0 \cdot 70$ & - & $18 \cdot 1$ \\
\hline 939 & 0.30 & - & $0 \cdot 80$ & - & $18 \cdot 0$ \\
\hline 889 & 4.99 & + & $1 \cdot 70$ & + & $17 \cdot 9$ \\
\hline 976 & $0 \cdot 17$ & - & $1 \cdot 20$ & + & $17 \cdot 8$ \\
\hline 441 & 3.40 & + & $0 \cdot 80$ & - & $17 \cdot 6$ \\
\hline 973 & $0 \cdot 28$ & - & $1 \cdot 28$ & + & $17 \cdot 3$ \\
\hline 966 & 1.92 & + & $1 \cdot 46$ & + & $17 \cdot 3$ \\
\hline 936 & $1 \cdot 21$ & + & 1.40 & + & $16 \cdot 3$ \\
\hline 444 & $0 \cdot 86$ & - & 1.00 & eq & $15 \cdot 4$ \\
\hline 980 & $0 \cdot 71$ & - & $1 \cdot 70$ & + & $12 \cdot 0$ \\
\hline 427 & $2 \cdot 06$ & + & 0.80 & - & 11.9 \\
\hline 929 & $2 \cdot 74$ & + & $1 \cdot 40$ & + & $11 \cdot 2$ \\
\hline 888 & $0 \cdot 25$ & - & $1 \cdot 10$ & + & $8 \cdot 2$ \\
\hline 925 & $1 \cdot 32$ & + & 1.50 & + & $6 \cdot 76$ \\
\hline 416 & $6 \cdot 89$ & + & $2 \cdot 80$ & + & $1 \cdot 3$ \\
\hline 895 & 6.02 & + & 1.90 & + & 1.0 \\
\hline
\end{tabular}

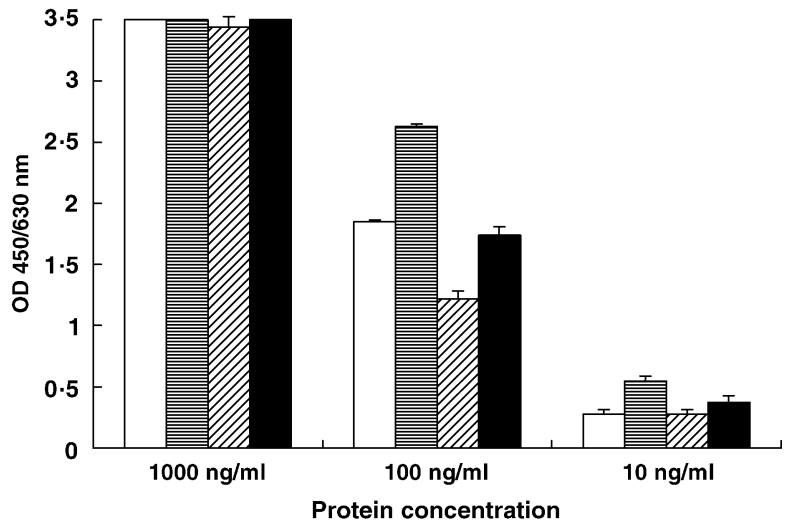

Fig. 3 Comparison of erythrovirus genotype 1 and 3 VP2 reactivity in the antigen enzyme immunoassay (EIA). Genotype 1 (clear and horizontal lined bars) and genotype 3 (diagonal lined and filled bars) recombinant VP2 was decimally diluted in either Tris-buffered saline Tween-20 (TBST) (clear and diagonal lined bars) or the proprietary low pH buffer (horizontal lined and filled bars). Error bars represent the standard deviation from the mean.

3 recombinant VP2 capsids exhibit indistinguishable reactivity in the assay to genotype 1 recombinant VP2 (Fig. 3).

\section{Donor sample evaluation}

During an 18-month period, approximately 1.4 million donations were tested for B19 DNA in The Netherlands [14], and 70 cases of asymptomatic donors (0.005\%) with levels of B19 DNA greater than $10^{6} \mathrm{IU} / \mathrm{ml}$ were identified. Of these, 49/70 (70\%) tested positive on the antigen EIA assay for B19 


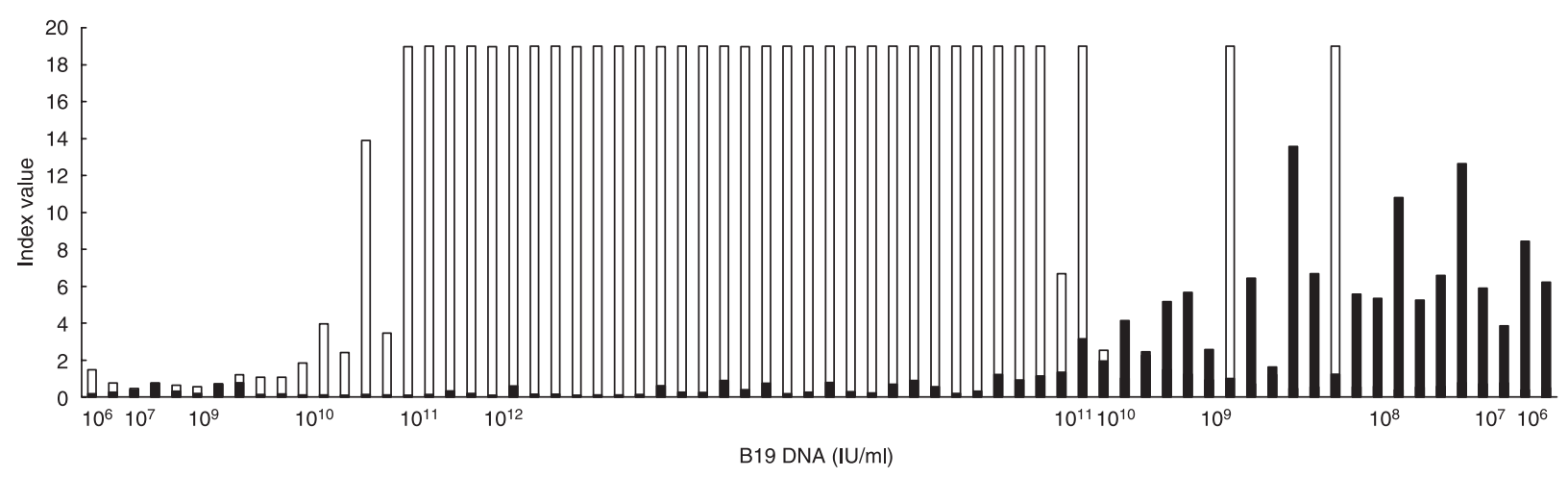

Fig. 4 A summary of the B19 antigen enzyme immunoassay (EIA) and immunoglobulin M (IgM) ElA reactivity of the panel of viraemic donors. An index value (IV) $>1 \cdot 1$ (denoted by line) is considered positive on both the B19 IgM EIA (filled bars) and antigen EIA (clear bars). The $y$-axis was truncated for clarity.

(range: $3 \cdot 1 \times 10^{6}-3 \cdot 2 \times 10^{12} \mathrm{IU} / \mathrm{ml}$; mean: $1 \cdot 1 \times 10^{12} \mathrm{IU} / \mathrm{ml}$, median: $1 \cdot 2 \times 10^{12} \mathrm{IU} / \mathrm{ml}$ B19 DNA) (Fig. 4). Thus, Fig. 4 depicts the combined B19 IgM and antigen EIA data of the 70 viraemic specimens, and the $x$-axis is arranged to show the rise $\left(10^{6}-10^{12} \mathrm{IU} / \mathrm{ml}\right)$ and subsequent drop in viraemia with the development of B19-specific IgM antibodies $\left(10^{12}-10^{6}\right.$ $\mathrm{IU} / \mathrm{ml}$ ). Testing further revealed that the panel of viraemic specimens was either pre- or early antibody seroconversion as none contained B19 IgG (data not shown).

There was a positive correlation (correlation coefficient $r=0 \cdot 81$ ) between the level of B19 DNA (qPCR) and the level of B19 antigenemia (antigen EIA), but this relationship was not directly proportional. Concordance between qPCR and the antigen EIA was highest when viraemia titres were high $\left(>1 \times 10^{11} \mathrm{IU} / \mathrm{ml}\right)$. Of the viraemic donor specimens, 27 (38.6\%) tested positive (IV $>1 \cdot 1$ ) or borderline positive (two specimens were equivocal: IV $\leq 1 \cdot 1, \mathrm{IV} \geq 0 \cdot 9$ ) for B19 IgM (Fig. 4). The specimens that were equivocal for IgM reactivity reacted strongly in the antigen EIA (IV > 19). The overlap between the two groups was considerable and $17 \%$ of the specimens tested positive for both B19 IgM and antigen (Fig. 4). Significantly, 91\% of the viraemic donors were positive for either B 19 IgM or antigen. Thus, these data clearly demonstrate that the combined implementation of a screening algorithm for B19 IgM and antigen readily facilitates the detection of specimens containing greater than $10^{6} \mathrm{IU} / \mathrm{ml}$ B19 DNA equivalents.

\section{Discussion}

Here we describe a B19 antigen EIA for the direct detection of B19 antigen in human plasma. The detection limit of the assay was $0.01 \mathrm{ng} / \mathrm{ml}$ of purified recombinant VP2 capsids (which theoretically corresponds to $1.9 \times 10^{6}$ viral particles per $\mathrm{ml}$ ). Using dilutions of viraemic serum, the sensitivity was estimated at between $4 \times 10^{7}$ and $10^{8}$ copies per ml B19 DNA equivalents. The antigen EIA was capable of detecting both erythrovirus genotypes 2 (virus) and 3 (recombinant capsids).
When the antigen assay was used to test B19 viraemic donations, $70 \%$ tested positive of which had viral loads between $3 \cdot 1 \times 10^{6}$ and $3 \cdot 2 \times 10^{12} \mathrm{IU} / \mathrm{ml}$.

B19 detection in plasma was greatly enhanced by specimen acidification. The low $\mathrm{pH}$ conditions may act by disrupting the viral capsid into its structural subunits, making it more accessible to the capture antibody. Although it was previously thought that B19V was highly resistant to physicochemical treatments, more recent work has shown the susceptibility of B19V to low pH treatment [24]. Boschetti et al. [24] showed that B19V was inactivated by greater than 5 logs after $2 \mathrm{~h}$ at pH 4 and that infectivity also decreased.

When the antigen assay was performed at physiological $\mathrm{pH}$, the specimens that gave the highest absorbance values were B19 IgM negative, implying immune complexes hinder detection. However, when specimens were prepared in low $\mathrm{pH}$ conditions, neither the presence of IgM nor IgG, even at high levels, affected the detection of B19 (Table 2). It is probable that acidification caused the dissociation of any immune complexes present. False-negative results due to immunocomplexes present a problem for B19 RHA assays, which exploit the binding of a B19V receptor to red blood cells [11]. Hence, the RHA assay is ineffective for antigen detection in specimens that have seroconverted a problem resolved by the B19 antigen EIA.

B19 detection by PCR has a greater sensitivity, but such assays have many disadvantages (e.g. potential cross-contamination) not shared with an EIA. First, although erythrovirus genotypes may diverge significantly at the genomic level [25,26], requiring primer optimization [13], there does not appear to be any antigenic or immunological differences between the genotypes. The antigen EIA could identify genotype 2 erythrovirus and genotype 3 recombinant VP2 capsids at the same sensitivity as genotype 1 . This is supported by the fact that all three erythrovirus genotypes can haemagglutinate human red blood cells and also infect myeloid cells with equal efficiency [27]. Second, the significance of DNA in plasma postviraemia 
is unclear as low levels of B19 DNA can persist for several years post-infection, even after IgM is lost and IgG reactivity has been established [28]. A virus detection assay, however, allows simultaneous testing of hundreds of specimens, is suitable for large-scale screening, is more economical and has a shorter time to result.

Combined B19 antigen and IgM EIA analysis of the viraemic donor specimens revealed that $91 \%$ of the donor specimens could be diagnosed as acute infection using this screening algorithm. Previously, clinical samples taken from individuals with a suspected B19 infection, which had a level of B19 DNA greater than $10^{5} \mathrm{IU} / \mathrm{ml}$, were shown to be positive for specific IgM also [20]. This was not the case with the Dutch donor specimens herein, as this panel was from asymptomatic individuals whose infection was detected due to routine screening. Donor specimens, therefore, would be from all stages post-infection including the preseroconversion stage. Experimental infection has shown that B19 infection has two phases [29], characterized by symptom-free initial high viraemia ( $10^{11}$ copies per ml serum) followed by detectable IgM antibody and appearance of symptoms such as rash and arthralgia. IgM seroconversion causes a rapid decline of viral titre. The 70 viraemic specimens identified in this study showed a typical viraemia and IgM seroconversion pattern (Fig. 4), confirming that the donor samples are representative of all stages of acute infection.

It is important to confirm the diagnosis of acute B19 infection in a public health setting where an outbreak could lead to serious medical consequences, especially for pregnant women and immunocompromised patients. In addition, B19 screening of blood donors prior to donation would avoid the risk of contaminating blood products. The B19 antigen EIA in conjunction with specific B19 IgM detection offers an effective method of detecting acute infection.

\section{Acknowledgements}

We are grateful to Jean Pierre Allain (University of Cambridge, UK) for providing recombinant genotype 3 VP2 protein. Financial support: Quality of Life and Management of Living Resources Program, Commission of the European Communities (project QLK2-CT-2001-00877 'Human Parvovirus Infection: Towards Improved Understanding, Diagnosis and Therapy’).

\section{References}

1 Kurtzman GJ, Cohen BJ, Meyers P, Amunullah A, Young NS: Persistent B19 parvovirus infection as a cause of severe chronic anemia in children with acute lymphocytic leukaemia. Lancet 1988; 2:1159- 1162

2 Wildig J, Michon P, Siba P, Mellombo M, Ura A, Mueller I, Cossart Y: Parvovirus B19 infection contributes to severe anemia in young children in Papua New Guinea. J Infect Dis 2006; 194:146- 153
3 Enders M, Weidner A, Zoellner I, Searle K, Enders G: Fetal morbidity and mortality after acute human parvovirus B19 infection in pregnancy: prospective evaluation of 1018 cases. Prenat Diagn 2004; 24:513-518

4 European Pharmacopoeia: European Pharmacopoeia Monograph of Human anti-D Immunoglobulin. European Pharmacopoeia, Strasbourg, France, 2004; Document 01:0557

5 Groeneveld K, van der Noordaa J: Blood products and parvovirus B19. Neth J Med 2003; 61:154-156

6 Prowse C, Ludlam CA, Yap PL: Human parvovirus B19 and blood products. Vox Sang 1997; 72:1- 10

7 Santagostino E, Mannucci PM, Gringeri A, Azzi A, Morfıni M, Musso R, Santoro R, Schiavoni M: Transmission of parvovirus B19 by coagulation factor concentrates exposed to 100 degrees C heat after lyophilization. Transfusion 1997; 37:517-522

8 Laub R, Stengers P: Parvovirus B19 and blood products. Pathol Biol 2002; 50:339-348

9 Hausler M, Scheithauer S, Ritter K, Kleines M: Molecular diagnosis of Epstein-Barr virus. Expert Rev Mol Diagn 2003; 3:81-92

10 Baylis SA, Shah N, Minor PD: Evaluation of different assays for the detection of parvovirus B19 DNA in human plasma. J Virol Methods 2004; 121:7-16

11 Sakata H, Ihara H, Sato S, Kato T, Ikeda H, Sekiguchi S: Efficiency of donor screening for human parvovirus B19 by the receptor-mediated hemagglutination assay method. Vox Sang 1999; 77:197-203

12 Koppelman M, Cuypers T, Emrich T, Zaaijer H: Quantitative real-time detection of parvovirus B19 DNA in plasma. Transfusion 2004; 44:97- 103

13 Aubin JT, Defer C, Vidaud M, Maniez Montreuil M, Flan B: Large-scale screening for human parvovirus B19 DNA by PCR: application to the quality control of plasma for fractionation. Vox Sang 2000; 78:7-12

14 Wong S, Brown KE: Development of an improved method of detection of infectious parvovirus B19. J Clin Virol 2006; 35:407-413

15 Takeda Y, Wakisaka A, Noguchi K, Murozuka T, Katsubayashi Y, Matsumoto S, Tomono T, Nishioka K: Receptor-mediated haemagglutination screening and reduction in the viral load of parvovirus B19 DNA in immunopurified Factor VIII concentrate (Cross Eight M). Vox Sang 2001; 81:266-268

16 Doyle S, Corcoran A: The immune response to parvovirus B19 exposure in previously seronegative and seropositive individuals. J Infect Dis 2006; 194:154-158

17 O'Keeffe S, O'Leary D, Doyle S, Kilty C, Kerr S: The detection of parvovirus B19 in human sera using antigen-capture EIA. Poster presented at the Society for General Microbiology (Irish Branch), National University of Ireland, Maynooth, Co. Kildare, Ireland, 24-25 April 2003

18 Lowin T, Raab U, Schroeder J, Franssila R, Modrow S: Parvovirus B19 VP2-proteins produced in Saccharomyces cerevisiae: comparison with VP2-particles produced by baculovirus-derived vectors. J Vet Med B Infect Dis Vet Public Health 2005; 52:348-352

19 Doyle S, Kerr S, O'Keeffe G, O'Carroll D, Daly P, Kilty C: Detection of parvovirus B19 IgM by antibody capture enzyme immunoassay: receiver operating characteristic analysis. J Virol Methods 2000; 90:143-152 
20 Beersma MF, Claas EC, Sopaheluakan T, Kroes AC: Parvovirus B19 viral loads in relation to VP1 and VP2 antibody responses in diagnostic blood samples. J Clin Virol 2005; 34:71-75

21 Kerr S, 0'Keeffe G, Kilty C, Doyle S: Undenatured parvovirus B19 antigens are essential for the accurate detection of parvovirus IgG. J Med Virol 1999; 57:179-185

22 Hermanson GT: Heterobifunctional Cross-Linkers; in Bioconjugate Techniques. San Diego, Academic Press, 1996:228-286

23 Saldanha J, Lelie N, Yu MW, Heath A: B19 Collaborative Study Group: Establishment of the first World Health Organization International Standard for human parvovirus B19 DNA nucleic acid amplification techniques. Vox Sang 2002; 82:24-31

24 Boschetti N, Niederhauser I, Kempf C, Stuhler A, Lower J, Blumel J: Different susceptibility of B19 virus and mice minute virus to low $\mathrm{pH}$ treatment. Transfusion 2004; 44:1079-1086

25 Nguyen QT, Wong S, Heegaard ED, Brown K: Identification and characterisation of a second novel human erythrovirus variant, A6. Virology 2002; 301:374-380

26 Servant A, Laperche S, Lallemand F, Marinho V, De Saint Maur G, Meritet JF, Garbarg-Chenon A: Genetic diversity within human erythroviruses: identification of three genotypes. J Virol 2002; 76:9124-9134

27 Hokynar K, Ekman A, Kantola K, Kakkola L, Hedman L, Bonden H, Aberham C, Gessner M, Garbarg-Chenon A, Hedman K, SoderlundVenermo M: Biological and immunological relation of the three variants of human parvovirus B19. Poster presented at the XIth Parvovirus Conference, Les Diablerets, Switzerland, 27-31 August 2006

28 Cassinotti P, Siegl G: Quantitative evidence for persistence of human parvovirus B19 DNA in an immunocompetent individual. Eur J Clin Microbiol Infect Dis 2000; 19:886-887

29 Anderson MJ, Higgins PG, Davis LR, Willman JS, Jones SE, Kidd IM, Pattison JR, Tyrrell DA: Experimental parvovirus infection in humans. J Infect Dis 1985; 152:257-265 